\title{
PENINGKATAN KEMAMPUAN MEMBACA BAHASA JERMAN MELALUI PENDEKATAN SCIENTIFIC
}

\author{
Mutmainna ${ }^{1}$ dan Burhanuddin² \\ Fakultas Bahasa dan Sastra, Universitas Negeri Makassar \\ Email: tunnafisah@gmail.com ${ }^{1}$
}

\begin{abstract}
ABSTRAK
Tujuan penelitian ini ialah untuk meningkatkan kemampuan membaca siswa melalui pendekatan scientific approach. Penelitian ini merupakan penelitian tindakan kelas. Subjek penelitian ini ialah siswa kelas XI IPA 3 yang berjumlah 35 siswa. Penelitian tindakan kelas ini terdiri 2 siklus, setiap siklusnya terdiri atas perencanaan, tindakan, observasi, refleksi. Analisis data menggunakan teknik persentase. Hasil penelitian menunjukkan bahwa terdapat peningkatan hasil belajar melalui pendekatan scientific pada siswa.
\end{abstract}

Kata Kunci: Pembelajaran Bahasa Jerman, Scientific Approach, Classroom Action Research.

\begin{abstract}
The purpose of this study is to improve the ability to read German through the scientific approach of students class XI IPA SMAN 14 Gowa. This research is a classroom action research. The subjects of this study were students of class XI IPA 3 which amounted to 35 students. This classroom action research consists of two cycles. Each cycle consists of planning, execution, observation, and reflection. Data analysis in this research using percentage technique. The results of this study showed that there is an increase in learning achievement of German reading ability through scientific approach of students.
\end{abstract}

Keywords: German Language Learning, Scientific Approach, Reading Skill.

\section{PENDAHULUAN}

Bahasa merupakan suatu lambang dan mewakili sesuatu, karena itu bahasa memiliki makna yang berkaitan dengan segala aspek kehidupan dan alam masyarakat yang memakainya. Kebermaknaan tersebut menandakan bahwa bahasa merupakan alat komunikasi yang melibatkan berbagai jenis bahasa. Ada beberapa bahasa yang digunakan masyarakat sosial di Indonesia. Bahasa tersebut meliputi bahasa Inggris, Jerman, Mandarin, Belanda, Perancis, Arab dan lain-lain. Salah satu bahasa asing yang diajarkan di Sekolah Menengah Atas (SMA) sederajat adalah bahasa Jerman. Pembelajaran bahasa Jerman juga diatur dalam kurikulum 2013.

Kompetensi yang diajarkan dalam pembelajaran bahasa Jerman yakni: keterampilan berbicara (Sprechfertigkeit), kemampuan menyimak (Hörverstehen), kemampuan membaca (Leseverstehen), keterampilan menulis (Schreibfertigkeit). Keempat kompetensi di atas juga ditunjang oleh kemampuan tambahan, yakni; tata bahasa dan kosa kata (Strukturen und Wortschazt). Dari kompetensi inilah siswa diharapkan mampu menguasai bahasa Jerman dengan baik. Salah satu kemampuan 
yang dapat meningkatkan pengetahuan siswa dalam mempelajari bahasa Jerman adalah kemampuan membaca. dengan kemampuan membaca ini, diharapkan siswa dapat mengembangkan rasa ingin tahu dan semangat belajar mengenai bahasa Jerman. Indikator pencapaian kompetensi kemampuan membaca yang diatur dalam kurikulum 2013 ditekankan pada kemampuan siswa dalam menganalisis dan memahami kata, frasa, dan kalimat yang terdapat pada bacaan.

Berdasarkan hasil observasi dan wawancara dengan guru bidang studi bahasa Jerman di SMA Negeri 14 Gowa, diperoleh informasi bahwa siswa mengalami kesulitan dalam memahami teks bahasa Jerman sehingga kemampuan membaca memahami siswa masih rendah. Hal tersebut tentunya dapat memengaruhi prestasi ataupun motivasi akademik peserta didik (Romadloni et all, 2017; Mantasiah et all, 2018). Rendahnya pemahaman siswa dalam kemampuan membaca bahasa Jerman di SMA didukung oleh beberapa hasil penelitian tentang kemampuan membaca. Suratmi (2014:51), mengemukakan bahwa kemampuan membaca memahami teks bahasa Jerman siswa SMA Negeri 8 MandaiMaros baru mencapai kategori cukup (66,96\%). Selanjutnya Harum (2015:43) menyimpulkan bahwa kemampuan membaca memahami teks bahasa Jerman siswa kelas XI IPA SMA Negeri 1 Makassar masih tergolong rendah $(41,66 \%)$. Lebih lanjut, Widyastuti (2013:47) mengemukakan bahwa kemampuan membaca memahami teks bahasa Jerman siswa kelas XI IPA SMA Negeri 1 Makassar masih rendah (54,94\%). Rendahnya pemahaman siswa dalam kemampuan membaca tersebut disebabkan kurangnya penguasaan kosa kata dan tata bahasa. Rendahnya penguasaan kosa kata dan tata bahasa tentunya bukan hanya memengaruhi aspek membaca saja, namun juga berpengaruh pada keterampilan lainnya seperti keterampilan menulis (Mantasiah et all, 2017; Qalbi et all, 2017), keterampilan berbicara (Harianto et all, 2017; Zulfikar, 2017; Tenri et all, 2017) dan keterampilan menyimak (Quddus et all, 2017; Yusri et all, 2017; Agnes et all, 2017).

Salah satu cara dalam mengatasi rendahnya pemahaman siswa di atas adalah penerapan pendekatan saintifik (scientific approach). Saintifik merupakan pendekatan yang diterapkan dalam kurikulum 2013 yang ditekankan pada lima tahap pembelajaran, yakni; mengamati (observing), menanya (questioning), menalar (association), mencoba (experimenting), dan membentuk jejaring sosial (networking). Kelima tahap tersebut akan memfasilitasi, memahami, memecahkan masalah, dan mengaplikasikan materi pembelajaran yang berbasis pada fakta atau fenomena yang dapat dijelaskan dengan logika atau penalaran tertentu, bukan sebatas kira-kira, khayalan, legenda, atau dongen semata.

Beberapa penelitian terkait pendekatan ilmiah (scientific approach) yang berhasil meningkatkan kemampuan siswa antara lain dilakukan oleh Kahar (2013:59) dalam hasil penelitiannya dikemukankan kemampuan membaca memahami teks bahasa Jerman siswa kelas XI SMA Kartika XX-1 Makassar dengan menggunakan metode pembelajaran Project Based Learning mengalami peningkatan dari $64 \%$ menjadi $75 \%$. Demikian pula penelitian yang dilakukan Hidayati (2013:25) yang mengemukakan bahwa pendekatan ilmiah (scientific approach) dapat meningkatkan hasil belajar siswa dari rata-rata $53 \%$ menjadi 
73\%. Lebih lanjut Satyawati (2011:37) dalam penelitiannya mengemukakan bahwa kemampuan membaca memahami siswa melalui pendekatan saintifik terbukti mampu meningkatkan kualitas pembelajaran dilihat dari kemampuan siswa dengan rata-rata $67 \%$ menjadi $85 \%$. Hasil penelitian di atas menunjukan bahwa pendekatan ilmiah (scientific approach) dapat meningkatkan prestasi belajar dan keterampilan ilmiah siswa.

\section{METODE PENELITIAN}

Jenis penelitian yang digunakan adalah Penelitian Tindakan Kelas (PTK). Penelitian tindakan kelas (Classroom Action Research) dipilih karena penelitian ini memiliki tujuan untuk memperbaiki dan meningkatkan kualitas pembelajaran dari proses pengkajian masalah pembelajaran di dalam kelas melalui refleksi untuk memecahkan masalah dengan cara melakukan berbagai tindakan yang terencana dalam situasi nyata serta menganalisis setiap pengaruh dari perlakuan (Jufri, 2017; Jufri, 2007). Penelitian ini dilaksanakan di SMA Negeri 14 Gowa. Subjek dalam penelitian ini adalah siswa kelas XI IPA 3 SMA Negeri 14 Gowa yang berjumlah 35 siswa dengan fokus penelitian adalah kemampuan membaca bahasa Jerman melalui pendekatan saintifik (scientific approach).

Penelitian ini menggunakan model yang dikembangkan oleh Suyadi (2015:50) yaitu; 1) perencanaan, 2) pelaksanaan, 3) pengamatan, 4) refleksi. Penelitian tindakan kelas untuk pembelajaran kemampuan membaca bahasa Jerman penulis menerapkan pendekatan saintifik dengan dua siklus. Pengumpulan data dalam penelitian ini terdiri atas observasi awal dengan guru bahasa Jerman, tes tertulis dan pedoman observasi.
Tes kemampuan membaca diberikan sebanyak satu kali di setiap akhir siklus. Bentuk teks yang diberikan terdiri atas wacana/teks bahasa Jerman materi Essen und Trinken.

Wacana/teks bahasa Jerman ini terdiri atas soal pilihan ganda (mehr Auswahl) sebanyak 10 butir soal, skor maksimal dari jawaban benar adalah 1 dan 0 untuk jawaban salah dimana skor maksimal untuk semua jawaban benar adalah 10 dan jenis soal benar-salah (richtig-falsch) yang terdiri atas 5 butir soal dengan skor untuk jawaban benar adalah 1 dan jawaban salah 0 . Skor maksimal untuk semua jawaban benar adalah 5 . Selanjutnya soal mencocokkan (Über einstimmung) sebanyak 10 butir soal, skor maksimal untuk semua jawaban benar 1 dan 0 untuk jawaban yang salah. Skor maksimal untuk seluruh soal adalah 25. Teknik analisis data yang digunakan dalam penelitian ini adalah menggunakan teknik persentase. Teknik persentase yang dimaksud adalah mencari skor rata-rata yang dicapai oleh siswa dari kemampuan membaca bahasa Jerman. Data yang diperoleh dari hasil tes kemudian dianalisis menggunakan uji beda $\mathrm{N}$-Gain guna mengukur besarnya mutu peningkatan kemampuan membaca bahasa Jerman siswa.

\section{HASIL DAN PEMBAHASAN}

Proses pembelajaran pada observasi awal, peneliti menemukan dan mencatat beberapa masalah berdasarkan pengamatan langsung di dalam kelas, antara lain sebagai berikut; 1) siswa mengalami kesulitan dalam memahami materi pelajaran, 2) siswa kurang berkonsentrasi saat membaca teks bahasa Jerman, 3) siswa tidak berani mengemukakan pendapat mengenai materi yang diajarkan, 4) siswa menganggap bahwa bahasa Jerman 
sulit untuk dipelajari, 5) siswa kurang latihan dalam membaca teks/wacana bahasa Jerman. Berdasarkan masalah yang teridentifikasi tersebut, maka peneliti dan guru berkolaborasi menyusun pemecahan masalah untuk pembelajaran bahasa Jerman. Adapun pemecahan masalah yang disepakati adalah sebagai berikut: (1) guru berupaya untuk mendorong siswa supaya aktif dalam kegiatan membaca bahasa Jerman melalui pendekatan saintifik. Dengan maksud guru dapat melibatkan siswa secara langsung agar dapat membaca efektif. Sehingga dapat diasumsikan bahwa keaktifan siswa untuk terlibat dalam pembelajaran bahasa Jerman meningkat dan kesulitan dalam kemampuan membaca dapat teratasi. (2) guru berupaya meningkatkan keaktifan siswa dengan cara memberikan banyak latihan bagi siswa sehingga dapat melatih kemampuan membaca bahasa Jerman siswa.

\section{Prosedur pelaksanaan Siklus I}

Pada tahap ini guru bertindak sebagai kolaborator aktifdalam proses pembelajaran dan peneliti sebagai partisipan pasif. Penelitian tindakan kelas siklus I dilaksanakan dalam 3 kali pertemuan. Pertemuan pertama dan kedua untuk pembelajaran sedangkan pertemuan ketiga untuk pemberian evaluasi/tes di akhir siklus. Setelah siswa diberi pemahaman tentang langkah-langkah pendekatan saintifik, guru menguji pemahaman siswa dengan memberikan teks/bacaan "im Gasthof" (Übung 11 seite 72 - Deutsch ist einfach) serta menyuruh siswa mengerjakan soal/ latihan. Di samping itu, peneliti mengamati dan mencatat hal-hal apa saja yang terjadi di dalam kelas termasuk keaktifan siswa selama mengikuti pelajaran. Pada pertemuan pertama, kegiatan pembelejaran belum bisa berjalan dengan efektif, karena masih banyak siswa yang melakukan aktifitas lain, dan pendekatan pembelajaran yang diterapkan oleh guru merupakan hal baru bagi siswa.

Peneliti melaksanakan pertemuan 2 siklus I. Guru memulai pelajaran dengan mengaitkan materi pada pertemuan sebelumnya. Selanjutnya guru membagi siswa menjadi beberapa kelompok lalu member materi pada buku Deutsch ist Einfach. Guru memberi penjelasan terkait materi yang dipelajari. Setelah itu, siswa diberi intruksi untuk mengamati bacaan, menanyakan hal-hal yang kurang dipahami, menyimpulkan isi dari bacaan kemudian memaparkan hasil pengamatan bersama dengan kelompok lain. Masing-masing kelompok diberi kesempatan untuk menyimpulkan hasil pengamatannya. Selanjutnya siswa diminta untuk mengerjakan latihan secara bersama-sama. Guru menjelaskan cara kerja latihan karena terdapat siswa yang kurang mengerti dan memahami perintah soal.

Pada pertemuan kedua, peneliti bersama kolaborator mendiskusikan hal-hal yang telah dicapai dan belum tercapai. Hal ini dapat terlihat dari kurangnya antusiasme siswa mengikuti pelajaran sehingga masih banyak siswa yang mengalami kesulitan untuk memahami materi pelajaran.Masih kurang siswa yang memberanikan diri untuk mengemukakan pendapat terkait pembelajaran. Selain itu, masih terdapat siswa yang bermain di kelas, mengganggu teman yang lain dan ribut pada saat jam pelajaran berlangsung.

\section{Prosedur pelaksanaan Siklus II}

Peneliti memposisikan diri dibelakang kelas agar kehadiranya tidak mengganggu proses pembelajaran tetapi berkedudukan sebagai partisipan pasif. Pertama-tama guru memberi intruksi kepada 
ketua kelas untuk menyiapkan kelas dan berdoa sebelum pelajaran dimulai. Setelah itu, guru mengucapkan salam dan menanyakan kabar siswa "Wie gehts euch? Selanjutnya guru mengecek kehadiran siswa satu persatu dengan jumlah 35 orang siswa.Pada pertemuan ini, seluruh siswa kelas XI IPA 3 hadir mengikuti pelajaran bahasa Jerman.

Pada pertemuan ini, peneliti bersama kolaborator mendiskusikan hal-hal yang perlu diperbaiki dalam kegiatan pembelajaran. Berdasarkan pengamatan pada pertemuan 1 siklus II, siswa sudah mampu mencari kosakata baru dengan kamus yang dimiliki maupun google terjemahan dari HP siswa. Namun, masih terdapat siswa yang berkeliaran pada saat pembelajaran berlangsung. Pada pertemuan 1 siklus II ini peneliti mencatat hal-hal yang masih perlu diperhatikan oleh guru pada saat pembelajaran. Seharusnya, guru mempersiapkan secara fisik dan psikologis agar siswa semakin antusias mengikuti pelajaran. Di samping itu, siswa juga harus memberikan motivasi kepada setiap siswa agar mereka semakin bersemangat dan aktif dalam proses pembelajaran, dan guru sekreatif mungkin mengkoordinir aktifitas siswa di kelas sehingga tidak tercipta suasana kelas yang gaduh, ribut serta tidak kondusif. Uraian tersebut menunjukkan bahwa masih perlu diadakan perbaikan cara penyajian guru untuk perencanaan pembelajaran pada pertemuan selanjutnya.

Berdasarkan hasil pengamatan dan evaluasi pada pertemuan 1 siklus II, maka guru dan peneliti menyepakati untuk melaksanakan pertemuan 2 siklus II dengan langkah-langkah pendekatan saintifik yang sama dan materi pembelajaran essen und trinkenpada buku Deutsch ist einfach. Di samping itu, guru berusaha menyajikan pembelajaran yang kondusif dengan mengacu pada rencana pelaksanaan pembelajaran dan meminimalisir terjadinya kekurangan-kekurangan seperti pada pertemuan sebelumnya.

Pada pertemuan 2 siklus II siswa mengikuti proses pembelajaran tertib dan tenang sehingga tercipta suasana yang kondusif selama pembelajaran. Siswa mulai aktif bertanya dan menanyakan hal-hal yang tidak dipahami pada materi yang diberikan oleh guru. Ketika guru memberi tindak lanjut berupa kosakata terkait materi, siswa berinisiatif sendiri untuk menemukan artinya dengan melihat kamus maupun mencari di google terjemahan. Siswa juga mampu membaca dengan baik dan memahami wacana yang diberikan sehingga mempermudah saat mengerjakan latihan. Pada siklus II terjadi perubahan yang signifikan, dimana aktifitas belajar dan respon positif siswa terhadap pembelajaran mengalami peningkatan. Hal ini dibuktikan saat pelaksanaan tindakan pada pertemuan pertama dan kedua siklus II, dimana siswa lebih antusias dan sangat memperhatikan penjelasan guru terkait materi pelajaran, siswa mulai mencoba dan menanyakan halhal yang belum dipahami, pada saat pembelajaran siswa mulai mengespresikan diri dengan terlibat aktif selama proses pembelajaran.

Pengamatan yang dilakukan peneliti dalam siklus I dan siklus II diperoleh hasil yang menunjukkan peningkatan aktifitas belajar siswa yang signifikan. Hal tersebut dapat dilihat dariperhatian siswa dalam memperhatikan penjelasan guru pada siklus II dengan rata-rata $(51,42 \%)$ dibandingkan pada siklus I hanya diperoleh persentase dengan rata-rata $(42,85 \%)$. Siswa juga 
mengalami peningkatan dalam mengemukakan pendapat terkait materi yang diajarkan oleh guru pada siklus II dengan rata-rata $(42,85 \%)$ dibandingkan pada siklus I yang hanya diperoleh rata-rata $(25,71 \%)$. Selain itu, kesadaran siswa untuk mengerjakan tugas tepat waktu mengalami perubahan pada siklus II dengan rata-rata (45.71\%) dibandingkan pada siklus I yang hanya diperoleh rata-rata $(31,42 \%)$. Selanjutnya, siswa lebih merespon posistif pendekatan yang diajarkan guru pada siklus II dengan rata-rata $(64.28 \%)$ dibandingkan pada siklus I yang hanya diperoleh rata-rata (50\%).Di samping itu, siswa lebih aktif menanyakan hal-hal yang kurang dipahami terkait materi yang diajarkan oleh guru pada siklus II dengan rata-rata $(52.85 \%)$ dibandingkan pada siklus I yang hanya diperoleh rata-rata $(41,42 \%)$. Lebih lanjut, siswa lebih bersemangat mengikuti pelajaran hingga akhir pada siklus II dengan rata-rata $(51.42 \%)$ dibandingkan pada siklus I yang hanya diperoleh rata-rata $(28.57 \%)$.

Skor hasil tes kemampuan membaca bahasa Jerman siswa juga mengalami peningkatan, dilihat dari nilai rata-rata yang diperoleh pada siklus I yakni 15,93 dengan persentase $63,72 \%$ mengalamipeningkatan pada siklus II dengan nilai rata-rata 20,54 dengan persentase $82,16 \%$. Untuk melihat perbedaan peningkatan yang terjadi pada siklus I dan siklus II peneliti menggunakan uji beda N-Gain. Hasil dari pengukuran $\mathrm{N}$ Gain tersebut, diketahui sebesar $(0,4)$ yang dapat diinterpretasikan dengan kriteria sedang. Dengan demikian, data hasil penelitian di atas menunjukan bahwa peningkatan kemampuan membaca bahasa Jerman melalui pendekatan saintifik siswa kelas XI IPA SMA Negeri 14 Gowa dinyatakan efektif.

\section{KESIMPULAN}

Penerapan pendekatan saintifik terbukti dapat meningkatkan kemampuan membaca bahasa Jerman siswa kelas XI IPA SMA Negeri 14 Gowa. Hasil yang didapatkan sangat memuaskan bagi peneliti karena hanya dengan dua siklus saja. Hasil tes kemampuan membaca bahasa jerman siswa dengan perolehan rata-rata siklus I adalah 15,93 dengan persentase $63,72 \%$ kemudian terjadi peningkatan pada siklus II dengan nilai rata-rata 20,54 dengan persentase $82,16 \%$. Penelitian mengenai peningkatan kemampuan membaca bahasa Jerman melalui Pendekatan Saintifik (Scientific Approach) ini diharapakan memberikan hasil yang bermanfaat. Adapun saran-saran yang ingin disampaikan diberikan kepada guru dan siswa. Diharapkan guru lebih efektif melanjutkan pembelajaran melalui pendekatan saintifik sehingga dapat meningkatkan kemampuan membaca siswa. Pada proses pembelajaran sebaiknya guru senantiasa membimbing dan melibatkan seluruh siswa aktif saat melalui tahapan-tahapan pendekatan saintifik. Siswa diharapkan senantiasa memiliki motivasi dan keaktifan yang tinggi dalam mempelajari bahasa Jerman. Selain itu diharapkan siswa lebih berkonsentrasi dalam belajar, aktif dalam proses pembelajaran dan senantiasa menjaga suasana kelas yang kondusif untuk belajar.

\section{DAFTAR PUSTAKA}

Abdin, Yunus. (2012). Pembelajaran Membaca Berbasis Pendidikan Karakter. Bandung: Refika Aditama. Abdullah, Ridwan. (2014). Pembelajaran Saintifik untuk Implementasi Kurikulum 2013. Jakarta: Bumi Aksara. 
Brown, H. D. (2001). Teaching By Priciple: An Interactive Approach To Language Pedagogy. San Francisco: Longman.

Daryanto. (2014). Pendekatan pembelajaran saintifik kurikulum 2013. Yogyakarta: Gava Media.

Harianto, H., \& Dalle, A. (2018). KEEFEKTIFAN MODEL PEMBELAJARAN KOOPERATIF TIPE BAMBOO DANCING DALAM KETERAMPILAN BERBICARA BAHASA JERMAN SISWA KELAS XI IPA SMA NEGERI 7 BULUKUMBA. Eralingua: Jurnal Pendidikan Bahasa Asing dan Sastra, 2(1).

Hidayati. (2013). Penerapan Pendekatan Saintifik untuk Meningkatkan Kemampuan Menerapkan Konsep Siswa SMA Negeri 2 Cileunyi. Bandung: Skripsi UIN Sunan Gunung Djati

Hosnan, Muhammad. (2014). Pendekatan Saintifik dan Kontekstual dalam Pembelajaran Abad 21. CiawiBogor: Ghalia Indonesia.

JUFRI, J. (2007). Metode Penelitian Bahasa, Sastra dan Budaya.

Jufri, J. (2007). Metode Penelitian Bahasa. Sastra dan Budaya.

JUFRI，J. (2017). Strategi Pembelajaran Bahasa.

Kahar, Kurniawan. (2013). Peningkatan Keterampilan Membaca Memahami Siswa Kelas Xi Sms Xx-1 Makassar Melalui Metode Project Based Learning Tipe Berbicara. Makassar: Skripsi FBS UNM.

Mantasiah, R. (2018, June). Pay It Forward Model in Foreign Language Learning to Increase Student's Self Efficacy and Academic Motivation. In Journal of Physics: Conference Series (Vol. 1028, No. 1, p. 012178). IOP Publishing

Mantasiah, R., Juffri, J., \& Yusri, Y. (2017). Keefektifan Model Pembelajaran Jaring Laba-Laba (Webbed) dalam Keterampilan Menulis Karangan Sederhana Bahasa Jerman. Indonesian Journal of Educational Studies, 20(2).

Pabumbun, A. R., \& Dalle, A. (2019). PROBLEMATIKA

PEMBELAJARAN KEMAMPUAN MENYIMAK BAHASA JERMAN SISWA KELAS XI SMAN 11 MAKASSAR. Eralingua: Jurnal Pendidikan Bahasa Asing dan Sastra, 1(2).

Qalbi, U. N., Mantasiah, R., Jufri, J., \& Yusri, Y. (2017). Efektivitas Model Pembelajaran Kooperatif Tipe Teams Games Tournaments dalam Keterampilan Menulis Bahasa Jerman Siswa Kelas XII IPA SMA Negeri 1 Bontonompo Kabupaten Gowa. Indonesian Journal of Educational Studies, 20(1).

Qudus, M., \& Yusri, Y. (2017). Keefektifan Penggunaan Metode Audio Lingual dalam Pembelajaran Kemampuan Menyimak Bahasa Jerman. Indonesian Journal of Educational Studies, 20(2).

Robbins, Stephen P. dan Timoty A. Judge. (2008). Perilaku Organisasi. edisi 12. Jakarta: Salemba Empat.

Romadloni, A., \& Mantasiah, R. Intercultural approach in foreign language learning to improve students' motivation. Senior Editors, 61. 
Sagala, Syaifuddin. (2005). Definisi Pendekatan Pembelajaran. Jurnal. Matematrix.id/ diakses pada 10 maret 2017.

Satyawati. (2011). Penerapan Pendekatan Saintifik dalam Pembelajaran Bahasa Arab Untuk Meningkatkan Minat Belajar Siswa SMA Negeri 15 Yogyakarta. Yogyakarta: Skripsi UIN Sunan Kalijaga.

Tenri, A., Asri, W. K., \& Azizah, L. (2017). KEEFEKTIFAN PENGGUNAAN MEDIA BRETTSPIEL DALAM KETERAMPILAN BERBICARA BAHASA JERMAN SISWA KELAS X SMA NEGERI 11 MAKASSAR. Eralingua: Jurnal Pendidikan Bahasa Asing dan Sastra, 1(1).

Westhoff, Gerard. (1997). Fertigkeit Lesen. Berlin: Langenscheidt.
Yusri, Y., Mantasiah, R., \& Jufri, J. (2018). The Use Of Two Stay Two Stray Model in English Teaching to Increase Student's Learning Outcome. Journal Of Advanced English Studies, 1(1), 39-43.

Zulfikar, Z., \& Azizah, L. (2017). KEEFEKTIFAN PENGGUNAAN MEDIA PEMBELAJARAN KARTU KUARTET DALAM PEMBELAJARAN KETERAMPILAN BERBICARA BAHASA JERMAN SISWA KELAS XI MA NEGERI 1 MAKASSAR. Eralingua: Jurnal Pendidikan Bahasa Asing dan Sastra, 1(2). 